\title{
INDONESIAN GOVERNMENT POLICY IN FOREST FIRE HANDLING
}

\author{
Nazifah \\ Mahasiswa Program Doktor (S3) Ilmu Hukum Universitas Jambi \\ Email : nazifahthojib@gmail.com \\ Meri Yarni \\ Mahasiswa Program Doktor (S3) Ilmu Hukum Universitas Jambi \\ Email : meriyarni@yahoo.com \\ Muhammad Amin Nasution \\ Mahasiswa Program Doktor (S3) Ilmu Hukum Universitas Jambi \\ Email : aminnasution13@yahoo.com
}

\begin{abstract}
Since 1997 until now, forest and land fires (Karhutla) in Indonesia occur almost every year. The 2015 Karhutla incident is believed to have burned 2.61 million hectares of forest and land. In 2016, even though Indonesia was hit by La Nina, forest and land fires continued to burn forest and land area of 14,604.84 hectares. Forest and land fires have a detrimental impact on the environment, social and economy. Even the problem of fires in Indonesia has caused smoke problems for neighboring countries, especially in the Southeast Asia region. The government has tried to deal with the forest and land fires both in the form of regulations and programs, but the forest fires still occur. Several studies have shown problems in handling forest and land fires, including difficulties. The government itself is aware that forest and land fire is a multidimensional problem that requires cross-sectoral coordination to deal with it.
\end{abstract}

Keywords: forest fires, Indonesia, policy

\section{Introduction}

As from 1997 to the present in 2019 forest and land fires (karthula) occur almost every year in Indonesia. Based on the data obtained, forest and land fires in 2015 burned forest and land area of 2.61 million hectares (BNPB, 2016), then in 2016 even though Indonesia was hit by la nina, forest and land fires continue to occur and burn forests and land covering an area of 438,363.19 hectares, in 2017 the

area of forest fires and land area of 165,483.92 hectares, continued in 2018 the area of forest and land fires occurred in 529,266.64 hectares, and in 2019 this forest fires according to KLHK data occurred in 28 provinces in Indonesia covering an area of 942,484.00 hectares (Directorate of PKHL, 2019).

Forest and land fires that occur are causing many losses, not only have 
an impact on confusion but also have an impact on social and economic life. Even forest and land fires that occur in Indonesia pose smoke problems for neighboring countries, especially in the Southeast Asian region (Heil, Langman, \& Aldrian, 2007). Forest and land fires have an impact on human life, both positive and negative. However, negative impacts dominate which include:

1) carbon gas emissions to the atmosphere thereby increasing global warming;

2) habitat loss for wildlife resulting in an ecosystem imbalance;

3) the loss of trees that are producing oxygen and absorbing rain water so that floods, landslides, and drought occur;

4) loss of industrial raw materials that will affect the economy;

5) reduced forest area which will affect microclimate (weather tends to be hot);

6) smoke pollution so that it disrupts community activities and causes various respiratory diseases; and

7) a decrease in the number of tourists

In the Grand Design document for the Prevention of Forest, Plantation and Land Fires issued by Bappenas, described in the last 15 years, 20002015, hotspot points exceeding 15,000 occurred in 2002, 2004, 2006,2009, 2014 and 2015. These fires occurred both inside and outside the concession. The average hotspots during that period were $45 \%$ in the concession area with details of $4 \%$ in the area of Timber Forest Product Utilization in Natural
Forest (IUPHHK-HA), 23\% in the Industrial Plantation Forest IUPHHK area, $16 \%$ in the plantation area oil palm (KKS) and $2 \%$ in the overlapping area of the three. The remaining 55\% occurs outside the concession area, namely $34 \%$ in forest areas and $21 \%$ in Other Use Areas (APL). The total area of fires in the period 2000-2015 reached 101,791,661 hectares which occurred 34\% inside the concession and $66 \%$ outside the concession (Bappenas, 2016).

Forest and land fires are mostly caused by human behavior, both intentional and due to their negligence. Only a small part is caused by nature (lightning or volcanic lava). The cause of fire by humans can be detailed as follows: (Qadriatun, 2014: 10).

1. land conversion, which is caused by the activity of preparing (burning) land for agriculture, industry, making roads, bridges, buildings, etc.

2. burning of vegetation, which is caused by intentional but uncontrolled burning of vegetation so that there is a jump fire, for example the clearing of industrial plantations (HTI) and plantations, or land preparation by the community;

3. the use of natural resources, which is caused by activities such as bush burning and cooking activities by illegal loggers or fish hunters in the forest;

4. the use of peatlands, which is caused by the activity of making canals or canals without being 
equipped with adequate control gates of water causing peat to become dry and flammable;

5. land disputes, which are caused by efforts by local communities to regain their rights to land or land looting activities that are often tinged with burning

The Indonesian government has tried to deal with forest and land fires both in the form of regulations and programs, but fires still occur in Indonesia. Several studies have shown that the causal factors that cause problems in handling forest and land fires include difficulties in coordination between related institutions, there is no appropriate division of authority between institutions, institutional forms that are ad hoc, policies on forest and land fire control that are not integrated, and weak law enforcement (Simorangkir \& Soemantri, 2002).

The government itself is aware of a multidimensional problem that

\section{Discussion}

\section{Forest Fires in Indonesia}

The forest is an invaluable natural resource because it contains biodiversity as a source of germplasm, a source of wood and non-timber forest products, regulating water systems, preventing floods and erosion and soil fertility, protecting the natural environment for the benefit of science, culture, recreation, tourism and so on. Therefore, forest utilization and protection have been regulated in the 1945 Constitution, Law No. 5 of 1990, Law No. 41 of 1999, requires cross-sectoral coordination to handle it. In this regard, the government formulated a coordinating strategy with the bureaucratic approach of Presidential Instruction (Inpres) No. 16 of 2011 concerning Improvement of Forest and Land Fire Control, which was updated with Inpres No. 11 of 2015 concerning Improvement of Forest and Land Control. In the last Inpres the government agencies involved in handling the issue of Forestry and Fire 15 Ministers, three Coordinating Ministers and seven Government Agencies (Budiningsih, 2017: 166).

Based on the description above, the writer wants to know how the Indonesian Government's policies in handling forest fires. This paper presents knowledge about the Government of Indonesia's policy in handling forest fires, considering that forest fires have become a routine that occurs every year.

Law No. 32 of 2009, PP No 28 of 1985 and several decisions of the Minister of Forestry as well as several decisions of the Director General of PHPA and the Director General of Forest Exploitation.

However, disruption to forest resources continues even intensifying. Forest destruction has increased carbon emissions by almost $20 \%$. This is very significant because carbon dioxide is one of the greenhouse gases that has implications for global warming trends. Snow and ice cover have declined, ocean temperatures have risen and sea level levels have 
risen from 100 to $200 \mathrm{~mm}$ during the last century. If the current rate continues, experts predict that the earth will be $1^{\circ} \mathrm{C}$ on average before 2025. Increasing sea levels can drown many regions. Extreme weather conditions that cause drought, floods and typhoons, as well as the distribution of organisms that cause disease, are predicted to occur. Forest fires are one form of disturbance that is increasingly common. The significant negative impacts caused by forest fires include ecological damage, declining biodiversity, declining economic value of forests and soil productivity, micro and global climate change, and smoke disturbing public health and disrupting transportation both land, river, lake, sea and air.

Smoke disruption due to Indonesia's forest fires has recently crossed national borders. Various efforts to prevent and protect forest fires have been carried out, including the effectiveness of legal instruments (laws, PPs, and Ministerial Decrees to Dirjen), but have not yet provided optimal results. Since the fairly large forest fires in 1982/83 in East Kalimantan, the intensity of forest fires has become more frequent and their distribution is increasingly widespread. The following recorded quite large fires were 1987, 1991, 1994 and 1997 to 2003 . Therefore, a detailed study was needed to prevent and overcome forest fires.

\section{Factors Causing Forest Fires}

Fire as an early tool or technology controlled by humans to change the environment and natural resources began in the mid to the end of the Paleolithic era, 1,400,000-700,000 years ago. Since humans recognize and master fire technology, fire is considered a basic capital for human development because it can be used to clear forests, improve the quality of grazing land, hunt wildlife, drive out wildlife, communicate socially around campfires and so on (Soeriaatmadja, 1997).

Analysis of the charcoal from the soil of Kalimantan shows that forests have been regularly burnt, starting at least 17,500 years ago. Large fires are likely to occur naturally during climatic periods that are drier than the current climate. However, humans also burned forests more than 10 thousand years ago to facilitate hunting and opening agricultural land. Written records of a century ago and oral history of forest dwellers confirm that forest fires are not new to Indonesia's forests (Schweithelm, J and D. Glover, 1999).

According to Danny (2001), the main cause of forest fires in East Kalimantan is due to human activities and only a small portion is caused by natural events. The natural fire process, according to Soeriaatmadja (1997), can occur because of lightning strikes, collisions of rock avalanches, coal seals, and stacks of srasahan. But according to Saharjo and Husaeni (1998), fires due to natural processes are very small and for the Kalimantan case is less than $1 \%$. Large forest fires are also triggered by the emergence of El-Nino climate phenomena such as 
fires that occurred in 1987, 1991, 1994 and 1997 (Office of the State Minister for the Environment and UNDP, 1998).

The development of these fires also shows the expansion of the spread of fire locations not only in East Kalimantan, but in almost all provinces, and not only in forest areas but also in non-forest lands. The cause of forest fires is still a topic of debate, whether due to natural or due to human activities. However, based on several research findings, the main cause of forest fires is the human factor that starts from the following activities or problems:

1. Traditional farming system of local residents who move around.

2. Forest clearing by forest concession holders for timber industries and oil palm plantations.

3. Structural causes, namely a combination of poverty, development policies and governance, causing conflicts between customary law and positive state law.

Shifting cultivation is a traditional agricultural effort in forest areas where land clearing is always done by burning because it is fast, cheap and practical. However, land clearing for cultivation is generally very limited and controlled because it has followed hereditary rules (Dove, 1988). Illegal fires may occur because of cultivation activities only as camouflage from illegal loggers who use $\mathrm{HPH}$ roads and are in the $\mathrm{HPH}$ area.

Forest clearing by HPH holders and plantation companies for the development of industrial plants and plantations generally covers a fairly large area. The method of land clearing by clear cutting and burning is the cheapest, easiest and fastest alternative land clearing. However, this method often results in fires not only limited to the area prepared for the development of industrial plants or plantations, but extends to protected forests, production forests and other land.

Whereas structural causes generally start with a conflict between the owners of capital in the timber and mining industries, and the indigenous people who feel that their traditional (adat) ownership of land, forest and land is controlled by investors who are authorized by positive state law. As a result, people's frustration was vented by burning down to defend the land they had owned for generations. Here poverty and injustice trigger forest fires and people will not want to participate to put it out.

\section{Indonesian Government's Policy in Handling Forest Fires}

Since the forest and land fires were large enough in 1982 and a series of forest fires in the following years, the Government of Indonesia has issued various policies in order to address this problem. Some laws and regulations that were born emphasized severe sanctions for perpetrators of forest and land 
burning, namely Law no. 41 of 1999 concerning Forestry; UU no. 18 of 2004 concerning Plantations, which is currently in the process of revision; UU no. 32 of 2009 concerning Environmental Protection and Management; and PP No. 45 of 2004 concerning Forest Protection which has been revised with PP No. 60 of 2009 (Qadriyatun, 2014: 10).

Forest fire control is generally carried out through efforts to prevent, suppress, and handle post-fire carried out at the national level to the level of forest management unit. Fire prevention efforts are carried out through public awareness campaigns; improvement of prevention technology, such as warning and prevention of forest fires, such as reservoirs, green belts, watch towers, and others; and software stabilization. Efforts to extinguish forest fires are carried out through enhancing extinction technology, extinction operations (early extinguishing and extending outages), and rescue and evacuation. Whereas post-fire management efforts are carried out by monitoring, evaluating and inventorying ex-fire forests; socialization and law enforcement; and rehabilitation. and PP No. 45 of 2004 concerning Forest Protection which has been revised with PP No. 60 of 2009 (Qadriyatun, 2014: 11).

The implementation of the policy was supported by structural institutions within the echelon II level of the Ministry of Forestry, namely the Directorate of Forest Fire and nonstructural institutions at the central to sub-district levels throughout Indonesia with a coordination mechanism. To support these efforts, the government also empowers communities around fire-prone forest areas. These communities face each other in the event of forest and land fires. Considering the importance of preventing and controlling forest and land fires, the Ministry of Forestry has a policy to involve the community in the prevention of forest and land fires through the formation of communitybased organizations, such as the Fire Concerned Community and the Fire Concern Group through Minister of Forestry Regulation No. 12 / MenhutII / 2009 concerning Forest Fire Control (Qadriyatun, 2014: 11).

Handling by the government in the case of forest and land fires is dominated by repressive measures, such as blackouts and law enforcement. If you look at the causes of forest and land fires as stated above, the policies adopted so far are only limited to addressing the problem of land clearing carried out by burning. Meanwhile, other causes such as land conversion, natural resource use activities, peatland utilization, land disputes have not been touched in forest and land fire control policies. Regarding land conversion, especially peatlands, based on Sawit Watch data, every year there is a conversion of forests into oil palm plantations of 200 - 300 thousand hectares. Conversion also occurs on peatlands. The limitation of mineral land and the relatively low issue of land tenure in the peatland area have resulted in the 
choice of peatlands to develop into other crops including oil palm. The conversion of peat swamp forest to oil palm plantations every year reaches 50-100 thousand hectares. Policies related to handling forest and land fires on peatlands should lead to a review of the licenses that have been granted for the development of oil palm plantations. This strategy is important to ensure that oil palm development should not lead to deforestation, peatland damage, and carbon emissions (Qadriyatun, 2014: 11).

Related to fires caused by fire from community activities during the utilization of natural resources, government policy through community awareness is appropriate. It's just that this program is not optimal for stopping forest fires. Community awareness campaigns should be followed by empowerment, so that people have other livelihoods that do not damage the forest. The mechanism of reward for environmental services can also be applied to provide stimulus to the community so that they want to preserve their forests (Qadriyatun, 2014: 12).

Regarding forest and land fires due to land disputes, reform of forest and land management policies is urgently needed. A review of overlapping forest and land use permits must be carried out immediately, especially on lands that overlap with customary community land. As long as the land dispute has not been resolved, the possibility of forest and land fires will continue to recur.

\section{Conclusion}

Forest and land fires have become routine national disasters. Various efforts have been made by the government by issuing various regulations and institutional formation. However, the control carried out emphasizes repressive rather than preventive measures so that it is less effective in dealing with forest and land fires so far. There needs to be an evaluation of forest and land fire management policies. The first effort is to reform forest and land management policies. Then proceed with a review of the land use permits that have been issued to overcome overlapping land use permits and peat land use permits. In addition, efforts must also be made to resolve land disputes, community empowerment, and law enforcement. In this regard, the DPR in carrying out its supervisory function needs to urge the government to immediately handle optimally and measurably the problem of forest fires that have caused disturbance and harm the community.. 
References

Bappenas. (2016). Grand design pencegahan kebakaran hutan kebun dan lahan. Jakarta:Bappenas

BNPB. (2016). Evaluasi penanggulangan bencana 2015 dan prediksi bencana 2016. Jakarta:BNPB

Boer C. 2002. Forestfire suppression in East Kalimantan Indonesia. Di dalam: Moore P, Ganz D, Tan L.C, Enters T, Durst P.B, editor. Prosidings of an International Conference on Community Involvement in Fire Management. Bangkok, Desember 2000. Bangkok: FAO.

Bowen MR, Bompard JM, Anderson IP, Guizol P, Gouyon A. 2001. Anthropogenic fires in Indonesia, a viem from Sumatra. Di dalam : radojevic $M$ \& Eaton P, editor. EU \& Departemen Kehutanan dan Perkebunan Republik Indonesia.

Budiningsih, K., Ekawati, S., Wibowo, A., \& Surati. 2015. Analisis konflik kepentingan lintas sektor dan konflik kewenangan antar institusi dalam penanggulangan kebakaran hutan dan lahan. (Laporan Hasil Penelitian). Bogor: Pusat Penelitian dan Pengembangan Sosial Ekonomi Kebijakan dan Perubahan Iklim Kementerian

Iskandar, J. 2000, Konservasi Keanekaragaman Hayati. Ulasan Pakar Mengenai
LingkunganHidup dan Kehutanan

Danny, W., 2001. Interaksi Ekologi dan Sosial Ekonomi Dengan Kebakaran di Hutan Propinsi Kalimantan Timur, Indonesia. Paper Presentasi pada Pusdiklat Kehutanan. Bogor.

Direktorat PKHL. 2019. Rekapitulasi Luas Kebakaran Hutan dan Lahan (Ha) Per Provinsi Di Indonesia Tahun 2014-2019. Jakarta: Direktorat PKHL Kementrian Lingkungan Hidup Dan Kehutanan RI.

Direktotar Jenderal Perlindungan Hutan dan Konservasi Alam, Jakarta. Fakultas Pertanian Universitas Lambung Mangkurat. 1995.

Direktotar Jenderal Perlindungan Hutan dan Konservasi Alam. 2003. Kebakaran Hutan Menurut Fungsi Hutan, Lima Tahun Terakhir.

Hartono, B. 1988. Kebakaran Hutan.

Direktorat Jenderal

Perlindungan Hutan dan Pelestarian Alam. Bogor.

Heil, A., Langmann, B., \& Aldrian, E. 2007. Indonesian peat and vegetation fire emissions: Study on factors influencing large-scale smoke haze pollution using a regional atmospheric chemistry model. Mitigation and Adaptation Strategies for Global Change, 12(1), 113-133.

Keaneka Ragaman Hayati. Yayasan Kehati.

Kantor Menteri Negara Lingkungan Hidup Republik Indonesia. 
1998. Kebakaran Hutan dan Lahan di Indonesia (Dampak, Faktor dan Evaluasi) Jilid 1. Jakarta

Qadriyatun, Sri Nurhayati. 2014. Kebijakan Penanganan Kebakaran Hutan dan Lahan. Info Singkat Kesejahteraan Sosial. Volume VI No.06

Simorangkir, D., \& Sumantri. 2002. A review of legal, regulatory and institutional aspects of forest and land fires in Indonesia. Bogor: Project FireFight South East Asia.

Survei dan Pemetaan Tanah Semi Detail Daerah Samarinda Propinsi Kal-Tim untuk Evaluasi Kerusakan dan Dampak Kebakaran Hutan Dari Api Bawah Tanah Terhadap Lingkungan. Banjarmasin. 